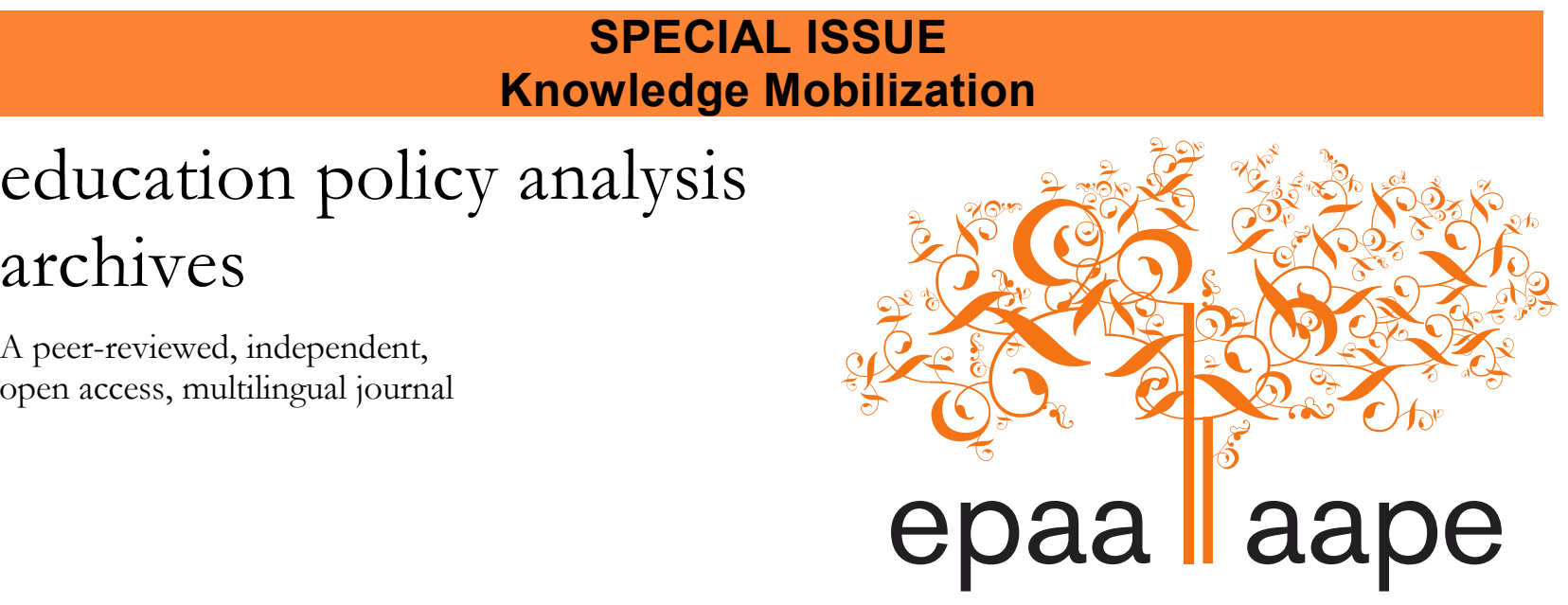

Arizona State University

ISSN 1068-2341

\title{
Mapping the Collaborative Research Process
}

\author{
Julie Reed Kochanek \\ ¿ \\ Carrie Scholz. \\ \& \\ Alicia N. Garcia \\ American Institutes for Research \\ United States
}

Citation: Kochanek, J. R., Scholz, C., \& Garcia, A. N. (2015). Mapping the collaborative research process. Education Policy Analysis Archives, 23(121). http://dx.doi.org/10.14507/epaa.v23.2031 This article is part of EPAA/AAPE's Special Issue on Knowledge Mobilization Guest Co-Edited by Dr. Amanda Cooper and Samantha Shewchuk.

Abstract: Despite significant federal investments in the production of high-quality education research, the direct use of that research in policy and practice is not evident. Some education researchers are increasingly employing collaborative research models that use structures and processes to integrate practitioners into the research process in an effort to produce more relevant and useful work. This article presents and describes the logic model developed by researchers at American Institutes for Research (AIR) to guide their work on the Regional Educational Laboratory Midwest. Under this program, AIR researchers have developed eight research alliances. The alliance members, who represent districts, state education agencies, and other organizations with a vested interest in education, partner with researchers to develop three- to five-year research agendas. These 
agendas drive the research and technical assistance projects that the alliance members and AIR researchers do together. It contributes to the emergent literature on research-practice partnerships, providing a theory-based approach to the work that others might model, build upon, or revisit.

Keywords: collaborative research; research-practice partnership; knowledge utilization; collaborative partnership; logic model; theory of action

\section{Mapeando el proceso de investigación colaborativa}

Resumen: A pesar de las inversiones federales significativas en la producción de investigaciones en educación de alta calidad, el uso directo de que la investigación en la política y la práctica no es evidente. Algunos investigadores en el área de educación están empleando cada vez más modelos de investigación en colaboración que utilizan estructuras y procesos para integrar los profesionales en el proceso de investigación, en un esfuerzo para producir un trabajo más relevante y útil. Este artículo presenta y describe el modelo lógico desarrollado por investigadores de la American Institutes for Research (AIR) para orientar su trabajo en el Laboratorio Educativo Regional del Medio Oeste. Bajo este programa, los investigadores de AIR han desarrollado ocho alianzas de investigación. Los miembros de la alianza, que representan a los distritos, las agencias estatales de educación y otras organizaciones interesados en la educación, forman un equipo con investigadores para desarrollar programas de investigación de tres a cinco años de duración. Estos programas de investigación y de asistencia técnica orientan a los miembros de la alianza e investigadores AIR en su colaboración. Este trabajo contribuye a la literatura sobre las asociaciones de investigación-práctica, proporcionando un enfoque teórico que otros podrían modelar, utilizar o modificar.

Palabras clave: investigación colaborativa; asociación de investigación-práctica; utilización de los conocimientos; asociación de colaboración; modelo lógico; teoría de la acción

\section{Mapeando o processo de pesquisa colaborativa}

Resumo: Apesar dos investimentos federais significativos na produção de pesquisas em educação de alta qualidade, o uso direto de investigação na política e na prática não é clara. Alguns pesquisadores no campo da educação estão cada vez mais usando modelos colaborativos de pesquisa que utilizem estruturas e processos para integrar os profissionais no processo de pesquisa em um esforço para produzir um trabalho mais relevante e útil. Este artigo apresenta e descreve o modelo lógico desenvolvido por pesquisadores do Instituto Americano de Pesquisa (AIR) para orientar o seu trabalho no Laboratório Educacional Regional do Centro-Oeste. No âmbito deste programa, os pesquisadores de AIR desenvolveram oito parcerias de investigação. Os membros da aliança, que representam distritos, agências estaduais de educação e outras organizações interessadas em educação, formaram parcerias com pesquisadores para desenvolver programas de investigação de três a cinco anos de duração. Estes programas de pesquisa e assistência técnica orientou a colaboração dos membros da aliança e pesquisadores da AIR. Este artigo contribui para a literatura sobre parcerias de investigação e prática, proporcionando uma abordagem teórica de modelagem que outros poderiam construir ou modificar.

Palavras-chave: investigação em colaboração; parceria de pesquisa prático; uso do conhecimento; parceria colaborativa; modelo lógico; teoria da ação

\section{Background}

In an effort to bring more knowledge about "what works" to education practitioners and policymakers, the Institute of Education Sciences (IES) has made significant investments in developing and disseminating focused, rigorous research projects in order to increase the supply of 
and demand for this research in education decision making (Honig \& Coburn, 2008). Serving as the research arm of the U.S. Department of Education, IES currently allocates more than $\$ 50$ million per year in new grants to support basic research. In addition to supporting new research efforts, IES is working to make published research more accessible to users. Some examples include moving the Education Resources Information Center (ERIC) to an online catalog of published and unpublished education research with indexes that allow keyword searches of the database, and creating the What Works Clearinghouse (WWC) to rate the rigor of selected studies to assist policymakers and practitioners in identifying programs with promising results. In addition to reviews of studies, WWC convenes panels of researchers to review bodies of literature to identify promising practices with ratings for the level of evidence supporting each recommended practice.

Despite this investment, practitioners and policymakers continue to make little direct use of research findings to drive state, district, school, and classroom decision making (Asen, Gurke, Conners, Solomon, \& Gumm, 2013; Burkhardt \& Schoenfeld, 2003; Finnigan \& Daly, 2014; Fusarelli, 2008; Hess, 2008; Kochanek \& Clifford, 2014; Lagemann, 2002). For example, studies of central office administrators found that they most often considered budgetary, political, and administrative issues when framing policy discussions, suggesting that the practicalities of district governance, rather than evidence, set parameters for decision making (Burkhardt \& Schoenfeld, 2003; Fusarelli, 2008; Lagemann, 2002). District administrators appear to weigh multiple forms of information simultaneously when making decisions rather than to rely on one or two instrumental student data points or research studies (Corcoran, Fuhrman, \& Belcher, 2001; Kennedy, 1982).

\section{Understanding Knowledge Utilization}

Given the persistent lack of direct use of research findings, a field of investigation has emerged to explore decision making in education policy and practice and the influences related to the use of research in decision making. This field, often referred to as the study of knowledge utilization, has found significant support from the William T. Grant Foundation, which has funded several studies of decision making at various levels of the education system, including federal policymaking (McDonnell \& Weatherford, 2014), state education agencies (Barnes, Goertz, \& Massell, 2014), district central offices (Kochanek \& Clifford, 2014), district school boards (Asen et al., 2013; Asen, Gurke, Solomon, Conners, \& Gumm, 2011), and schools (Daly \& Finnigan, 2012; Daly \& Finnigan, 2013; Finnigan \& Daly, 2014). Collectively, the work expanded understanding of the individual decision making process involving cycles of acquisition; interpretation; and use of research evidence nested within social, organizational, and political contexts.

Studies of knowledge utilization typically rely on the Weiss (1980) and Weiss, MurphyGraham, and Birkeland (2005) categories of use of evidence: instrumental, conceptual, symbolic, and sanctioning. Instrumental use of evidence involves the direct application to policy and practice that is often anticipated by traditional research dissemination mechanisms but is infrequently seen. More recent studies of research use have attempted to record the conceptual use of research-that is, when research provides users with a new perspective on existing understandings of problems and processes in educational policy or practice. Research is used symbolically when it is cited to legitimize preexisting conditions or decisions. Finally, as funding requirements for programming are increasingly linked to research-based interventions, we see the sanctioning use of research in which an external organization or authority defines the list of research-based practices and promotes their adoption in policy and practice.

Before research is used, it must be acquired, interpreted and processed into the existing understandings of educational contexts and processes - a step often labeled as sensemaking (see Figure 1). The acquisition stage is often characterized by an overload of information in which users must be selective about when to search, where to look, and what merits attention. In this context, 
reputations and relationships accompanying sources of information and the format used to present information become important factors in whether relevant research is acquired. Research coming from trusted sources typically has a stronger chance for acquisition (Kochanek \& Clifford, 2014). The interpretation stage involves similar patterns in which reports on research are disaggregated by users, often unintentionally, with some findings given more weight than others based on how the findings relate to preconceptions about the issue. Embracing some findings (or even parts of findings) while discarding others may result in mischaracterizations of research evidence.

Sensemaking occurs when new information is integrated with existing understandings. Because the acquisition and interpretation phase often privilege information that fits within an individual's understanding of contexts, problems, and solutions, typical sensemaking stages reaffirm one's beliefs and involve little alteration.

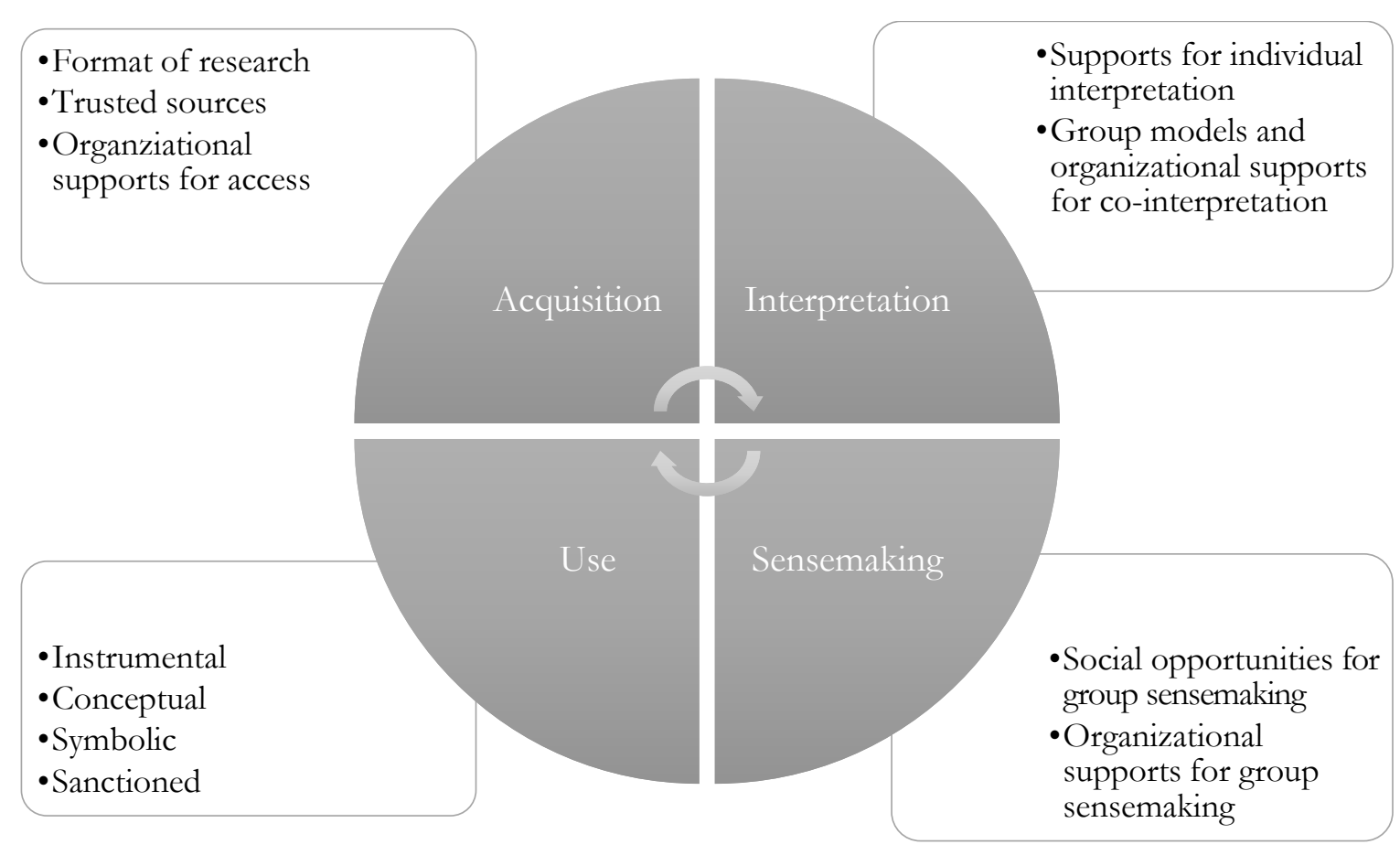

Figure 1. Knowledge Utilization Theory of Action

This cycle of acquisition, interpretation, sensemaking, and use may occur at both individual and group levels, as shown in Figure 1 (Coburn, 2005; Coburn, Honig, \& Stein, 2009). Individuals may access research on their own or through social connections. Individuals may work together in subgroups within an organization, and organizational supports may promote research acquisition and interpretation (Glennan, Bodilly, Galegher, \& Kerr, 2004; Honig, 2006). For example, shared meeting time may enable a group process in which individuals not only share research evidence with one another but also discuss the research in ways that lead to common sensemaking of the evidence. In short, knowledge utilization is situated in social and organizational contexts that influence individual actions.

\section{Collaborative Research to Support Knowledge Utilization}

Increasingly, education researchers are recognizing the structural division between researchers and practitioners and are looking for new ways to integrate practitioners into the research process as collaborators (Bryk \& Gomez, 2008; Bryk, Gomez, \& Grunow, 2010a; Burkhardt \& Schoenfeld, 2003; Coburn \& Stein, 2010; Committee on a Strategic Education 
Research Partnership, 2003; Hiebert, Gallimore, \& Stigler, 2002). Proponents of emerging models of collaborative research argue that involving practitioners in the research process bridges the divide between research and practice, builds capacity to incorporate systematic inquiry into regular decision-making processes within practitioner communities, and informs the research process itself by bringing together experts from diverse perspectives to engage in problem-solving work so that research and practice become part of an interactive cycle supporting improvement (Bryk \& Gomez, 2008; Bryk et al, 2010a; Bryk, Sebring, Allensworth, Luppescu, \& Easton, 2010b; Coburn \& Stein, 2010; Roderick, Easton, \& Sebring, 2009).

The research-practice partnership between the University of Chicago Consortium on Chicago School Research (CCSR) and Chicago Public Schools (CPS) is often cited as a model for research-practice partnerships (Research Alliance for New York City Schools, 2011; Roderick et al., 2009; Tseng, 2012). Founded in the early 1990s, CCSR assembled researchers from across universities to examine CPS reform efforts. The organization attracted foundation funding for both operational and research funding. CCSR uses a steering committee of stakeholders such as district and community group leaders to inform the development of a research agenda and the progress of individual studies. In addition, it maintains ties to district offices and schools across the district so that research teams have frequent contact with potential audiences for their findings. Many similar research-practice partnerships have emerged throughout the past 15 years, including the Baltimore Education Research Consortium, the Stanford-San Francisco Unified School District Partnership, and the Research Alliance for New York City Schools.

When CCSR director John Easton was appointed director of IES in 2009, the collaborative research model pioneered in Chicago influenced new grant and program funding efforts. IES created a line of research funding to provide seed money for the development of researcherpractitioner partnerships. A second funding line was developed to support integrated researcher, developer, and practitioner teams engaged in the design, implementation, and testing of interventions through continuous cycles of improvement. An existing funding line targeting rigorous evaluations of state and local policies brought new emphasis to the role of the partnership between the research team and the education agency whose policy is under study. Finally, the regional educational laboratory (REL) program was restructured to become the strongest example of Easton's support for collaborative research models.

\section{Promoting Collaborative Research Through the REL Program}

The REL program originated in 1965 as a federally funded program intended to create a link between the education research and development field and school districts. For decades, RELs served as intermediary organizations bundling existing research into tools and resources to be used by state and district education agencies. When IES was created in 2002, the REL scope of work shifted to the supply of primary research in response to the needs of state and district agencies. During this period, the REL contractors changed the personnel working under the contracts to include higher skilled researchers. IES approved studies that provided descriptive analyses using state or district data or randomized controlled trials that investigated the impact of programs. This shift was accompanied by an emphasis on scientific rigor in research generation and efforts to inform education policymakers and practitioners about a hierarchy of levels of research evidence. Researchers during this iteration of the REL program were positioned as experts, and the vision for working with those in policy and practice was a unidirectional approach of dissemination of findings from experts to practitioners and expectations of use in decision making.

Under the most recent contract influenced by Easton's vision, the REL program requires the development of research alliances as the basis for providing research support services. The new contracts, based on each of 10 laboratories forming and/or joining research alliances as a context for 
rigorous analytic work has resulted in 79 research alliances across the country supported by $\$ 54$ million per year. The scope of work for these alliances is intended to build state and local education agency capacity to use data and conduct research, develop a cohesive body of knowledge in core priority areas identified in each region, and increase the use of data and research in education decision making. Program outcomes also include the development of strong relationships among those in research, policy, and practice and the completion of a range of rigorous studies that employ the appropriate research design for the research questions.

Although there is significant overlap among RELs in the content areas identified as priorities for their alliances, the RELs have adopted a variety of models for research alliances-multidistrict, multistate, single jurisdiction, and cross-level (state and district combined). In addition, each REL contractor has developed different structures and work plans that are designed to increase opportunities for stakeholder collaboration in the research process while also maintaining high-quality research practices. As the RELs entered this new line of work, there were few models to follow and little systematic research on how best to form, build, and maintain research partnerships. Our team at REL Midwest, which is operated by American Institutes for Research (AIR), developed a logic model for collaborative research to guide our work and to illustrate the connections between our structures and intended outcomes. Taking into consideration the contexts in which our alliance members work, we began to map out the inputs, processes, and outputs of collaborative research to bring our assumptions about how to build relationships, group identity, and research use to the forefront of discussions. We investigated extant literature on these topics and created strategies and structures based on what we learned. We developed feedback loops to provide formative data on process and interim outcomes to further hone our model. The result is the logic model displayed in Figure 2.

This article describes the model and how it guides the work of REL Midwest. It contributes to the emergent literature on research-practice partnerships, providing a theory-based approach to the work that others might model, build upon, or revisit. We recognize that this model is one amid many possible collaborative research models. It is somewhat specific to the context provided by the funding mechanism. To date, we have not rigorously tested our model. However, we present the model here as a description of our work and the resources and processes that we employ as a building block for research on collaborative models. Researchers interested in building collaborative partnerships may adapt some of our processes for their own work. Researchers interested in testing the efficacy of collaborative research models may use this model to build measurement and research designs in future studies. 


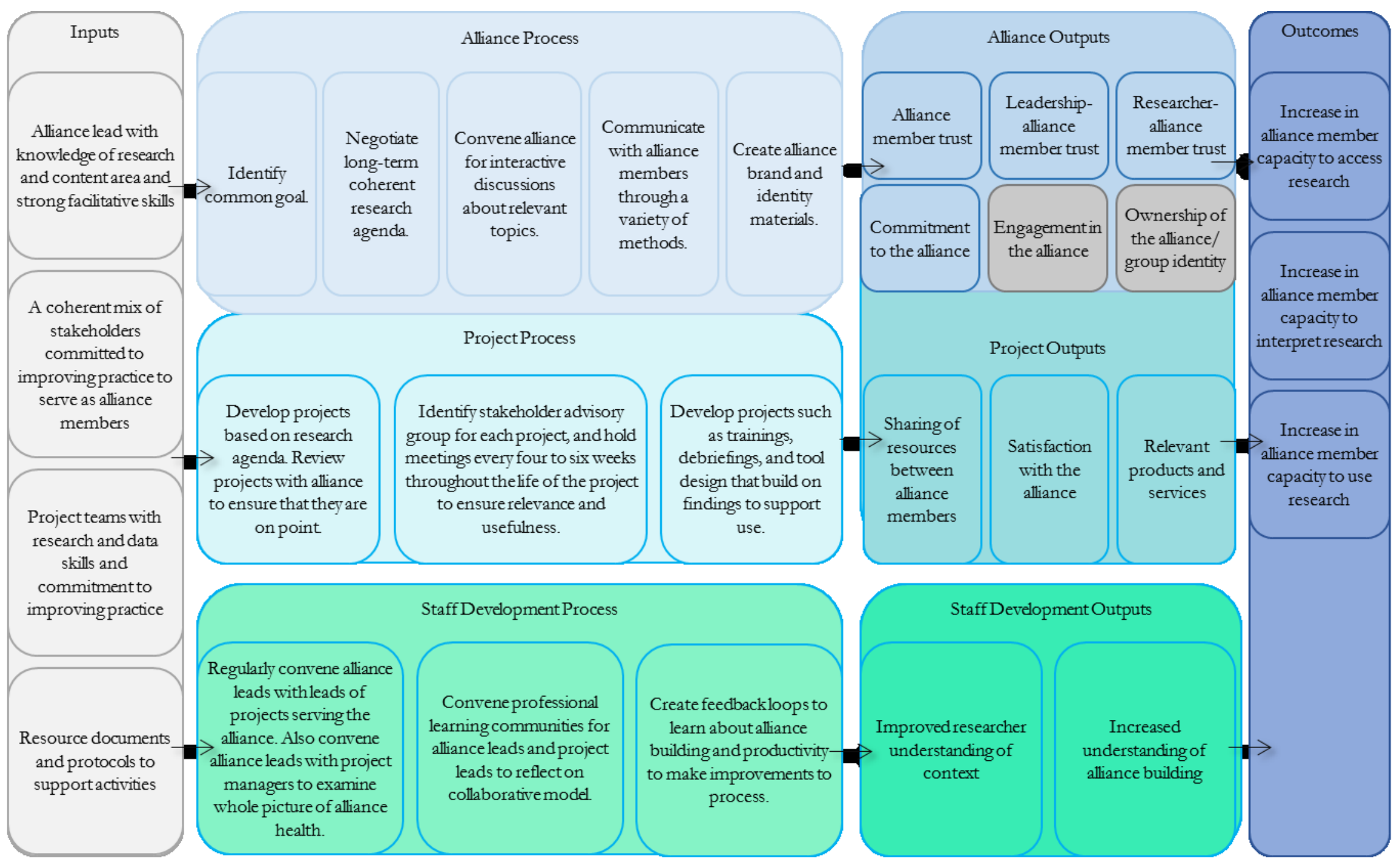

Figure 2. Collaborative Research Logic Model 


\section{Inputs That Set the Stage for Collaboration}

As mentioned earlier, IES requested that REL contractors such as AIR use a collaborative research approach based on the formation of research alliances to identify the research and technical assistance projects to be completed under the five-year contract. The REL Midwest research alliances comprise researchers and education stakeholders working together toward a common research agenda. Each of REL Midwest's eight alliances addresses a different education topic such as educator effectiveness, early childhood education, and college and career readiness. The stakeholders participating in the alliances involve a variety of groups interested in the topic of focus to the research alliance (e.g., policymakers, practitioners, community members, etc.).

This section of the article will highlight the first piece of the AIR-developed collaborative research logic model developed to guide the alliance work-inputs. The first three inputs are focused on the various individuals involved in the collaborative research process: a strong alliance lead, project teams with research and data skills for alliance work, and alliance members committed to improving practice. The last input focuses on the documents and tools developed to support the individuals involved in the collaborative research process.

\section{Strong Alliance Leads}

At REL Midwest, we believe the most important input is a strong facilitator as the alliance lead. A REL Midwest alliance lead has five key responsibilities: (1) coordinates alliance activities, (2) connects the REL Midwest project team(s) and alliance members, (3) collaborates with other research alliance leads, (4) serves as the primary point of contact for the research alliance, and (5) conducts needs-sensing and outreach activities with stakeholders in the region. To effectively fulfill each of these responsibilities, we recruited individuals with knowledge of the content area relevant to the alliance topic, awareness of the political contexts in the jurisdictions represented by the alliance, and strong facilitation skills.

In some cases, it was difficult to identify an individual in possession of the appropriate combination of content knowledge, political awareness, and facilitation skills. To ensure the most successful alliance experience, we gave priority to the facilitation skills component. The primary responsibility of an alliance lead involves the coordination of alliance activities. This responsibility includes scheduling, planning, and facilitating alliance convenings. During these convenings, a strong alliance lead must be able to create a participatory decision-making environment within the research alliance. The four components of participatory decision making include encouraging full participation from each alliance member, promoting mutual understanding among alliance members, fostering inclusive solutions when diverse views arise, and cultivating shared responsibility among alliance members (Kaner, 2007). A strong alliance lead must be comfortable implementing multiple facilitation practices to effectively create the participatory decision-making environment. Some of these practices include, but are not limited to, respecting diverse communication styles, drawing people out, tracking ideas, balancing viewpoints, intentional silence, listening for common ground, and summarizing (Kaner, 2007). This environment creates opportunities to build the capacity and effectiveness of the group as a whole, while also encouraging personal learning for the alliance members and the alliance lead (Kaner, 2007). Within the participatory decision-making environment, alliance members should be able to reach a place of sustained agreement as they work together to identify a research agenda and the specific projects necessary to address the questions identified in that agenda. 
REL Midwest alliance leads serve as the primary point of contact for research alliance members. This role requires that alliance leads connect with alliance members outside of research alliance convenings by phone, email, or in-person visits to provide resources relevant to their context and answer any questions they may have about specific research projects or the collaborative research process. By serving in this role, alliance leads are able to build strong, trusting relationships with alliance members. These relationships contribute to the success of the research alliance; as alliance members become more comfortable with the alliance lead, they are likely to become more involved in the alliance convenings and the participatory decision-making process.

By fulfilling each of these responsibilities, AIR alliance leads often serve in the role of research broker - the intermediary between researchers and practitioners. Alliance leads are research brokers both within and outside of the research alliance. Alliance convenings often include discussions regarding the application of research to education practice. These conversations may involve research conducted by the alliance or external research relevant to the work of the alliance. Regardless of the source of the research, the alliance lead must be able to navigate the conversation in a way that directly promotes the use of education research by alliance members. The alliance lead must replicate this effort during conversations with education stakeholders who are not alliance members but whose work will benefit from the use of the alliance's research. The ability of the alliance lead to effectively bridge the gap between researchers and practitioners is critical to the success of the research alliance and the impact of the alliance's work on education practice.

\section{Alliance Members Committed to Improving Practice}

The second key input in this collaborative research approach is the recruitment and participation of alliance members who are committed to improving education practice. The first step in this process is to identify potential alliance members. REL Midwest research alliance members are often identified based on their work in a particular content area (e.g., a state director of educator licensing is asked to participate in the Educator Effectiveness Research Alliance). However, alliance members are not required to be content experts to participate in the research alliance; they may also be identified because the work of the alliance may inform their practice (e.g., a state director of the division for school improvement also participates on the Educator Effectiveness Research Alliance).

When identifying potential alliance members, REL Midwest's goal is to find individuals who have an interest in the topic, who are committed to improving education practice, and whose experience will allow them to contribute to the alliance convenings in a meaningful way. REL Midwest will then reach out to these individuals (often the alliance lead will make this initial contact) to describe the research alliance topic and goals and invite them to participate. During this initial engagement, REL Midwest will also solicit suggestions for additional alliance members to continue the recruitment process. As an alliance is built, REL Midwest concentrates on achieving the right mix of alliance members to create a strong and productive research alliance.

Two key factors influence alliance composition: attention to power dynamics and the need for alliance members who play a variety of roles. Paying attention to power dynamics is often as simple as paying attention to job titles. For example, the inclusion of a district superintendent may affect the participation of that district's principals in the alliance. The principals may not feel that they can openly share their problems of practice if their boss is also participating in the conversation. Similarly, a representative from the state education agency may discourage the superintendent's participation. Attention to these dynamics may affect who REL Midwest invites to participate in the alliance. Although it may be beneficial to have varied perspectives on the topic, in this example, the benefit of the superintendent's perspective may not justify the cost of the discouraged participation of the principals. Therefore, the alliance lead must consider the issue of 
power dynamics when building the alliance. In some cases, the final alliance membership does result in some tension related to power dynamics. In these instances, the alliance lead must use strong facilitation skills during the convenings to alleviate the tension and create an open environment for all alliance members to participate.

The second key factor in alliance composition involves the inclusion of alliance members who play a variety of roles, including champions, advisors, stakeholders, boundary spanners, and learners. When planning projects, we look for alliance members who might serve as champions of the work. These members are typically decision makers in their organizations and have the power to commit organizational resources to partner on the project. Champions often designate staff to work with our project teams to inform our work and maintain its usefulness. This designated staff fulfills the advisor role on the alliance. We also ensure that we have alliance members who are part of stakeholder groups that will make use of the findings, tools, or trainings that come from the alliance. These stakeholder members may serve as advisors or champions, but in some cases, this is an independent role. Just as an alliance lead may span the boundaries between REL researchers and alliance members, we look for alliance members to serve as boundary spanners both within and outside of the alliance. To find boundary spanners for an alliance, REL Midwest seeks to identify individuals who have strong working relationships with other alliance members or with networking groups outside of the alliance. It is particularly beneficial if these relationships cross organizations or organizational structures (see, e.g., Hubbard, 2010). Finally, we recognize that some alliance members may join in the less active role of learner. Learners do not typically contribute in more active ways on alliance projects or discussions. However, they play the role of the internal audience for alliance work. Alliance members may play different roles for different projects that serve the alliance. However, at REL Midwest, we identify the core alliance members that actively engage in our work as the steering committee. This group holds the authority to guide our work while also shouldering the responsibility to play the active roles of champion, advisor, stakeholder, and boundary spanner.

\section{Project Teams With Research and Data Skills for Collaboration}

The third key input for the success of a collaborative research approach is the involvement of project teams with the right set of research and data skills. The skills of the team members must be strong enough to instill confidence in the alliance members that the research alliance will produce meaningful work. In addition, the project team members must have the ability to use those skills to effectively complete the alliance work. To meet these goals, project team members must have content area expertise in the topic relevant to the research alliance or must be experts in the methodological approach identified for the project.

In addition to these research and data skills, project team members should be fully tuned into the alliance's research agenda and understand what tools and processes might better support the alliance members' efforts to improve education practice. To do their work well, the project lead must engage with the alliance members in a meaningful way throughout each stage of the project. At REL Midwest, we have specific structures described in the next section to increase project leads' understanding of the alliance goals and encourage them to approach the project with a collaborative research mind-set. This mind-set focuses the project team's attention to considering how the results of their work may be used by alliance members and other education stakeholders to improve education practice - a focus that makes the alliance project work more meaningful for both the project teams and the alliance members. 


\section{Resource Documents and Protocols to Support Alliance Activities}

The final input for the collaborative research model is the creation of resource documents and protocols that support alliance activities. These documents are beneficial across research alliances. REL Midwest has developed a series of templates and examples for use by alliance leads, including:

- Alliance convening agenda

- Alliance theory of action

- Roles and responsibilities documents for staff and alliance member roles

- Memorandum of understanding for use with alliance members

- Research agenda development protocols

- Meeting facilitation protocols

- Protocols for discussion of project work at each phase of a project

- Engagement plans to support use of findings

REL Midwest has developed documents that outline the roles and responsibilities of the alliance lead, the project lead, and the alliance member-documents that provide information and guidelines about major activities expected in each role and how those roles interact with one another. Each of these resources serves to inform and support the staff and alliance members as they move to the next step of the collaborative research logic model-processes. These documents and protocols are further described in the following section.

\section{Processes Driving and Nurturing the Collaborative Research Partnership}

The work of our collaborative research partnerships is developed and sustained through processes at three different levels: the alliance, the project, and the REL Midwest staff. In the following sections, we define the purposes of each process and outline their essential activities labeled in the logic model (see Figure 2). Although this section may read like a checklist of activities (i.e., once one activity is completed you move on to the next), each process and corresponding activities need to be continuously revisited and nurtured. The outputs and outcomes of the work will either (re)confirm the decisions made and supports provided throughout the collaborative partnership's processes and activities or suggest opportunities for refinement.

\section{Alliance Process}

The alliance process sits at the top of the logic model and is reiterated in Figure 3. The purpose of the alliance process is to create and sustain a collaborative partnership. To do this, we work with our alliance members across five key activities: identify a common goal, negotiate a threeto five-year coherent research agenda, convene alliances four to 12 times per year for interactive discussions about relevant topics, communicate with alliance members through a variety of mechanisms, and create alliance brand and identity materials. 


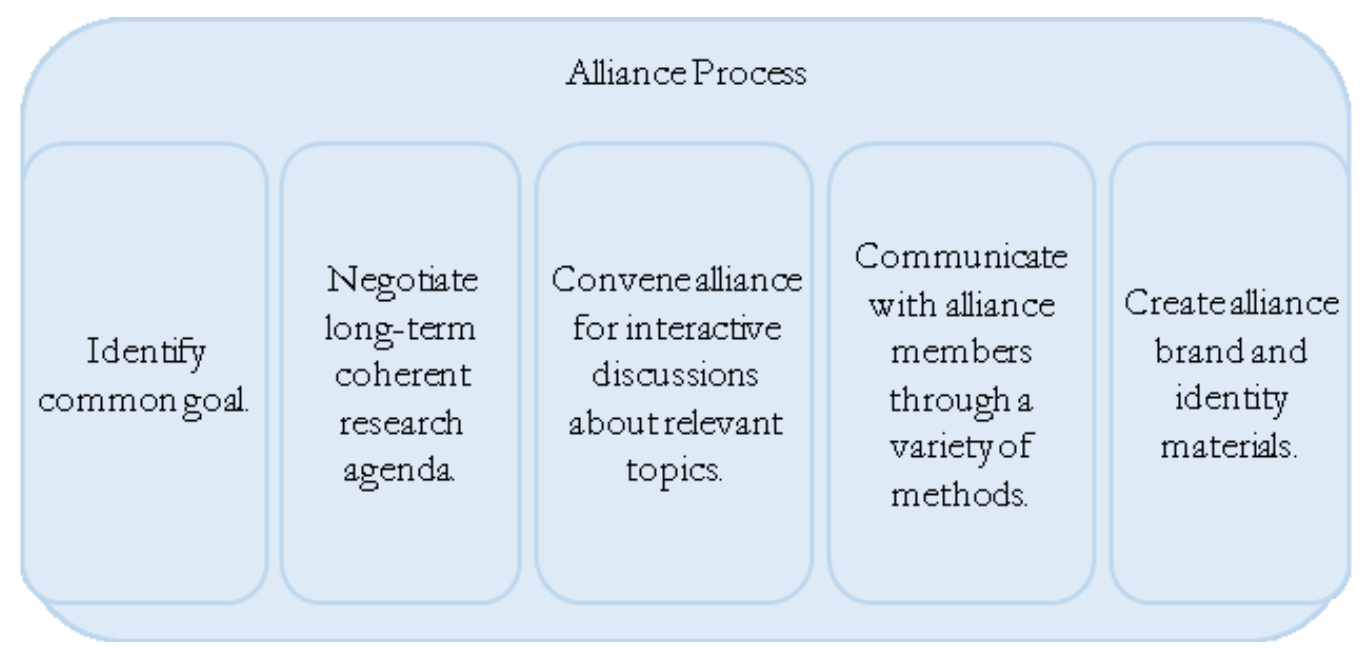

Figure 3. Activities to Promote Collaborative Partnerships

Identify a common goal. Before inviting partners to identify a common goal, REL Midwest strategically conducted needs-sensing activities (e.g., surveyed education stakeholders, met with state education agencies and district leaders, conducted policy scans) to identify the education priorities of educators, administrators, and policymakers. We aligned these priorities with those put forward by our funder, IES, and recruited potential alliance members to partner with us. The priority areas common to our region and our funder are college and career readiness, early childhood education, educator effectiveness, and low-performing schools and school improvement. A general goal for each alliance is to conduct research that will drive improvement in one of these priority areas; however, agreeing upon the specifics (i.e., what research) is essential to mobilizing a collaborative research partnership. Therefore, it is critical to address the second activity in our logic model under the alliance process: negotiate a three - to five-year coherent research agenda.

Negotiate a three- to five-year coherent research agenda. REL Midwest has adapted a structured "workshop" developed by REL Northeast and Islands (REL-NEI) to introduce the concept and process of developing a grounded research agenda (for more information, visit http://www.relnei.org/publications/workshop-materials-for-setting-a-coherent-researchagenda.html). The purposes of the one- to two-day workshop are to further identify priorities and winnow those priorities into a set of research questions that lend themselves to an important, coherent research agenda. The agenda-setting workshops are led by a trained REL Midwest staff member (the alliance lead), and the workshop participants are the members of a given alliance. Each workshop is typically divided into two sessions.

During the first session, the REL Midwest staff members provide an overview of types of research and how methods relate to research questions. The researchers then walk through the characteristics of and process for developing a researchable question and aligning questions with study designs. With this overview in mind, the alliance members are then asked to begin to generate research topics they think the alliance should address. This portion of the workshop is where the partners begin to unpack the overarching priority area that brought them together (e.g., early childhood, college and career readiness), which builds capacity on both sides of the partnership. As the alliance members generate topics for consideration, the researchers and alliance members have an opportunity to gain a more intimate understanding of all of the alliance members' needs and the challenges within their contexts. Throughout the discussion, the research topics are captured and made available for all to see and reflect upon. Researchers 
often determine research needs by identifying gaps in the literature. Practitioners must act within a more structured context, sometimes making policy and practice decisions on topics not yet investigated through the research. For example, our research team working with the Virtual Education Research Alliance initially expected to focus their work on the conditions under which online learning might have a stronger impact. The alliance members were focused on how to prepare and support teachers moving to an online or hybrid format. Discussions about pressing decisions in practice helped the research team better understand priority topics for the alliance and how to design projects to support alliance member decision making.

Using that initial list of topics as a springboard, REL Midwest staff members then facilitate a discussion to refine the list. The alliance members have an opportunity to ask clarifying questions about the topics, choose one to three topics that could drive a research agenda, and then vote on which topic(s) to prioritize. This short list of topics is the outcome of the workshop's first session.

Often, the topics from the first session still remain far too broad and require a similar discussion and voting process to narrow the list of subtopics and research questions under each topic. Each iteration of the conversation offers researchers and alliance members the opportunity to ask clarifying questions and to check whether the rephrasing of a given question still captures the alliance members' intent. These exchanges build the researchers' capacity to become more adept in their appreciation of the members' needs and the specific questions they want to answer. After multiple conversations and note taking, the researchers and alliance members have a visual that shows them how they have narrowed their focus from a research priority to a list of specific research questions. With this list, the REL Midwest staff members and alliance members embark on the last two portions of the workshop-establishing the research agenda and discussing interest in participation and data availability.

To create a finite list of research questions that will define the alliance's research agenda, the REL Midwest staff members facilitate a discussion with the alliance members to come to a consensus on the answers to questions that include the following:

- How many of the top-rated questions should the research agenda comprise?

- Do these questions inspire a coherent set of work?

- What might be the types of studies (descriptive, correlational, and impact evaluations)?

- What is the right (or a possible) sequence?

- What are the anticipated research products (e.g., workshops, tools, work processes) that will enable stakeholders to use the knowledge produced by the research?

- What is the timing of the work?

While addressing each of these questions, the alliance members and researchers continue to refine the research questions and determine how many they will tackle over a three- to five-year period. This refinement process continues to happen on at least an annual basis to ensure that the alliance is deriving useful information from the collaborative research efforts and conducting the right projects to build upon the new knowledge, tools, and resources generated by their work.

To end the agenda-setting workshop, the collaborative research partners discuss who will represent the alliance on the particular research projects and to what extent might extant data be leveraged to answer specific research questions. REL Midwest staff members capture these conversations and then share the draft research agenda and corresponding timeline and request alliance members to provide feedback at the next alliance convening. 
Convene alliances four to 12 times per year. Under the REL Midwest contract, the alliances meet, at a minimum, four times per year; however, several of the alliances meet much more frequently. Virtual conference calls are a convenient mechanism for convening the alliance members and REL Midwest staff members spread across the region. At least once per year, the alliances hold an in-person meeting.

Each convening offers a unique opportunity for alliance members and REL Midwest staff members to further develop and maintain the collaborative research partnership and connect alliance members with their role-alike peers in different states, districts, etc., to strengthen their professional network and learn from each other's experiences. External speakers are often invited to share additional resources and tools aligned with the alliances' research agendas. These meetings serve as a platform for group acquisition, interpretation, and sensemaking of research evidence. As such, it strengthens the individual acquisition, interpretation, and sensemaking cycle to support the use of research. Using the convening structure as a model, alliance members may create a similar structure in their organizations, such as an informal learning community among program heads to support the use of research.

Communication with alliance members. Outside of convenings, the alliance leads meet with alliance members in different configurations (e.g., subcommittees or working groups, one-on-one) to discuss the alliances' ongoing work, the extent to which the partnership is meeting the members' needs, and additional opportunities in which REL Midwest may support the members' organizations. REL Midwest staff create newsletters to keep members up-to-date on project status and to document the activities of the alliances. Finally, alliance leads generate group e-mails that regularly share new publications or events on the alliance topics and encourage alliance members to share with one another.

Create alliance brand and identity materials. Each alliance has inward- and outwardfacing documents that help to build, solidify, and communicate to others about its unique identity. The inward-facing documents are the alliance's theory of action and roles and responsibilities. The documents shared with those outside of the alliance are the research agenda, the alliance newsletters, and the alliance overview - a one-page graphic summarizing the alliance's goals, membership, and projects to date. The creation of outward-facing documents is an integral step in establishing and maintaining the alliance's identity. These documents inform others about the alliance's contributions to the field of education, help to recruit members, and serve as a piece for current members to reflect upon and see the benefits and outcomes of their invested time and energy.

Theory of action. The alliance's theory of action defines the need that the partnership's research will address, outlines the roles potential alliance members and their research partners will play and codifies the anticipated work products and corresponding benefits of the partnership. Typically, the alliance's theory of action is developed once the alliance establishes its research agenda. The alliance lead facilitates a series of discussions focused on the four columns in the diagram. Starting with the end in mind, the alliance members and researchers engage in identifying the anticipated benefits of the partnership and its research. The next step requires the alliance members and researchers to review the list of work products they generated as an outcome of their research agenda-setting workshop and determine the extent to which the work products and benefits align (and revise as necessary). Next is a discussion about the specific activities (i.e., strategic planning, technical assistance, and research), necessary roles to complete those activities, and the need the alliance agreed to address through its research. Finally, moving from left to right in the template, the partners review the extent to which their discussions and decisions are reflected in the template and make revisions as necessary. Every 
alliance's theory of action should be revisited at least once per year to inco rporate any changes and/or (re)confirm these key elements.

Roles and responsibilities. One mechanism for ensuring that the theory of action is realized by the alliance and its partners is the articulation of agreement to fulfill the roles and responsibilities necessary to meet the alliance's goals. The alliance's roles and responsibilities documents contain at least five essential ingredients: the alliance's mission statement, the benefits of the work (as articulated in the theory of action), opportunities for participation, membership expectations, and a one-year time frame for the partners' commitments. The roles and responsibilities documents push the partners to think about the expectations they have for each other as well as what they are accountable for in the collaboration. Having an agreed-upon document to revisit if or when a partner is not fulfilling a particular role can ease the challenges associated with those conversations. On a more positive note, these documents also provide alliance members' organizations with a deeper understanding of what their staff members are being asked to do as part of the partnership. Often, alliance members serve on boards, committees, etc. These documents clearly articulate that the level of commitment needed for a partnership is different from the other volunteer efforts and that if they participate, their time needs to be protected. In addition to codifying roles and responsibilities for current members, these inward-facing documents are sometimes used in an outward-facing way to recruit new alliance members. Potential partners want to know what they are being asked to do. Walking through the roles and responsibilities documents with them will help to inform them about those opportunities and expectations. Such documents often help to convince individuals to engage as an alliance member because they value the thoughtfulness put into these documents, the clarity related to their new role, and the intentional plan to revisit their commitment within one year to determine whether they plan to continue participating in the alliance.

The alliance overview. Each of the REL Midwest alliances has a one-page handout that succinctly describes REL Midwest's mission, the alliance's goals, and the alliance's guiding research questions. These documents also list the members and their organizations, the alliance's specific research and technical assistance projects' goals and corresponding activities, and the conferences and other related events in which the alliance participated. For an example of an alliance overview, visit http://www.relmidwest.org/sites/default/files/Early $\% 20$ Childhood $\% 20$ Education$\% 20$ Research $\% 20$ Alliance $\% 20$ Handout 1.pdf.

Research agenda. A companion piece to an alliance's one-page handout is its research agenda. This document begins to take shape after the agenda-setting workshop mentioned earlier. Specifically, its content demonstrates how the alliance's research questions build upon one another and drive a coherent body of work designed to yield practical tools and resources for practitioners, administrators, and policymakers. There is often a visual component that communicates the projected timeline for the completion of the work. The research agenda complements the one-page handout by providing more information about the completed work while also previewing the work to come.

Alliance newsletters. Although REL Midwest publishes a newsletter for general distribution, we develop alliance-specific newsletters once or twice yearly to highlight alliance activities. The newsletters contain project updates, spotlights on alliance members, a letter from the alliance lead that focuses on a relevant issue area, and stories about how alliance members have used products and services of the alliance. For an example of an alliance newsletter, visit http://www.relmidwest.org/sites/default/files/newsletters/REL Dropout Newsletter 508.pdf 


\section{Project Process}

Occurring concurrently with much of the work of the alliance process, the project process involves many of the same participants (alliance leads, alliance members, project teams). The purpose of this process is to intentionally codesign and conduct the work in such a way that it equally values and leverages the alliance members' and researchers' unique expertise. In collaboration with alliance members, REL Midwest uses three types of activities to ensure that the projects are relevant and useful. These activities are defined in the following paragraphs and pulled from the logic model for reference here in Figure 4.

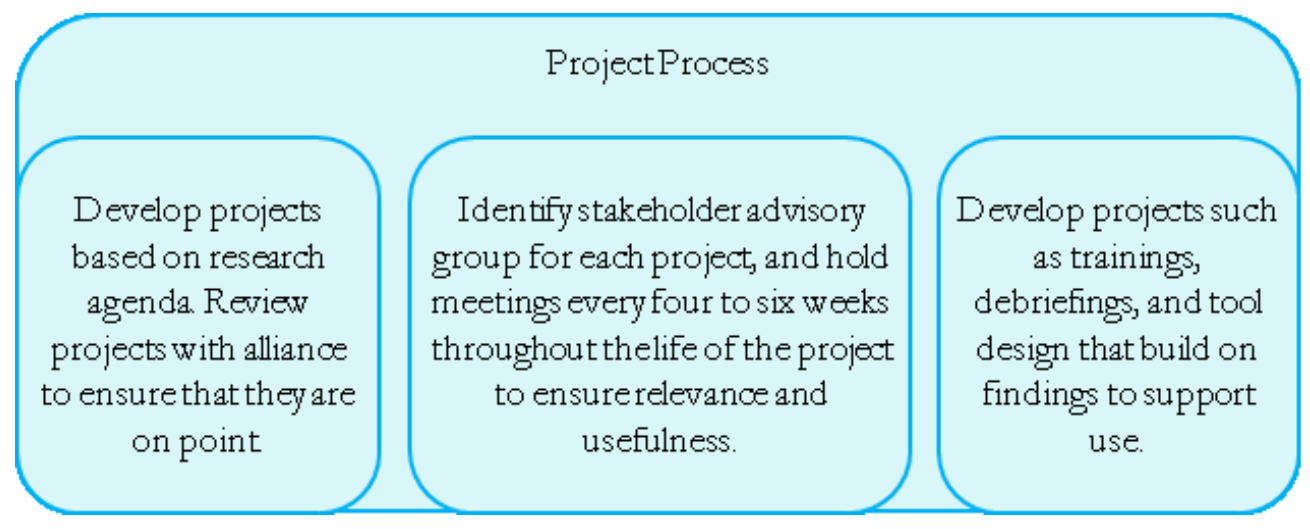

Figure 4. Activities to Support Collaborative Projects

Develop projects based on research agenda. As part of the agenda-setting workshop described earlier, the members of the alliance and REL Midwest staff begin to outline the projects that compose their research agenda. This conversation must be revisited at least annually to ensure that the projects are addressing the alliance's needs. In addition, as projects are designed to address research questions, alliance members are asked to revisit the questions in light of the project design. We specifically ask whether our projects are addressing the questions as members intended. At times, these conversations bring misunderstandings to the surface, signaling quickly that our project design, while appropriate for the research questions, does not meet the core need of the alliance members. For example, we initially proposed a study of data use to address alliance member questions about how to increase data use in teacher practice. After discussions of the concept, we realized that alliance members really wanted to address these questions through skill-building workshops on data inquiry cycles. In other cases, these conversations have revealed practitioner beliefs about certain research methods that make them less likely to trust the findings of a study. In all cases, we have attempted to ground projects solidly in alliance member needs to better position our work to result in relevant and useful products.

Identify a stakeholder advisory group for each project. As projects move from concept to formal proposal, we recruit a stakeholder advisory group (SAG) for each project. An SAG is a subgroup of alliance members or designees from their organizations who meet regularly with a project team to ensure that the resulting products and services from the project are relevant and useful for the intended stakeholders. SAG members are active partners with REL Midwest researchers on the project team, and SAG feedback is critical to the project's success.

Each SAG typically has two to three members recruited from the alliance, alliance member organizations, or organizations that supply data or sites for a project. SA G members 
are recruited to fit the design of the project with attention to including individuals who can inform the project, who might learn from and replicate the project, and who might make use of the end product. For example, if the project involves a study using data from a district, it is helpful to include someone in the SAG who knows the data elements and can speak about data quality. If another district is interested in replicating the study, it is helpful to recruit a member from that district's organization to learn from the project team discussions about questions and challenges encountered along the way. If the study will likely have findings that inform district policy, it is helpful to include someone who can discuss the format for the end product and related services (such as tools, trainings, or debriefings) that might help the district make use of the findings. Similarly, if the project involves an event, it is helpful to include a SAG member who can help bring the audience to the event.

In general, the SAG meets every four to six weeks during the life of a given project to discuss decisions made by the REL Midwest project team that shape the project. The topics will vary depending on the stage and type of the project. At the beginning of a project, a concept paper can be used as a project road map in which each section can be reviewed and discussed. When discussing a research project, for example, the discussions with the SAG may focus on confirming the research questions, framing the problem, determining the sampling strategy, identifying the data sources, and reviewing protocols and methods. SAG members will have varying levels of expertise to discuss and weigh in on these topics. However, even on the topic of methods, for which the REL Midwest project team may want to claim greater expertise, we take care to solicit and listen for feedback from SAG members. It is often during conversations about the reasons for choosing a method from the project team and reservations about the use of a method by the stakeholders that each side learns about and better understands the contexts of research and practice. When a project team attempts to find solutions to stakeholder concerns while maintaining the integrity of the project, stakeholders are more likely to find the project relevant and useful.

Develop projects that build on findings to support use. The alliance's research is not designed to end with a traditional research report. Instead, each project is crafted with application in mind. The application vehicles may be more targeted research briefs developed for a specific audience that highlight findings over methods without using technical jargon. We also develop infographics and videos to highlight findings in easily accessible formats. Usually, our projects include facilitated debriefings with stakeholders to highlight results and discuss the implications for their context. In some cases, we develop tools or ancillary materials to accompany the findings of a study to relieve some of the barriers to use of findings in practice. In these cases, the conversations with our alliance members have played key roles in helping us understand what barriers exist and how we might address them. For other projects, we develop trainings or workshops based on report findings to assist states or districts in communicating findings to the school level and provide a format for practitioners to reflect on next steps for their school or classroom. Moving from producing technical reports to designing and developing supports within our projects has been a creative shift for our project teams. However, this shift has highlighted the importance of understanding stakeholder context for their work.

\section{Staff Development Process}

Engaging in a collaborative research partnership and conducting collaborative research projects are not skills that are typically promoted by the postsecondary institutions that train the staff at REL Midwest. To foster these skills, we center our staff development process on the three key activities described in the following paragraphs and displayed graphically in Figure 5. 


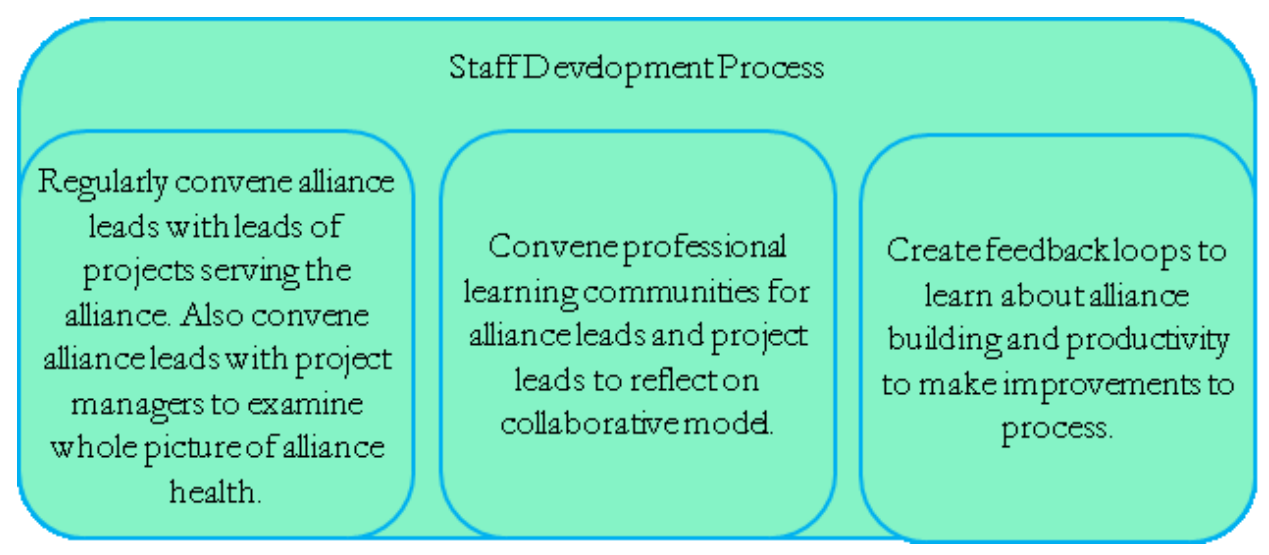

Figure 5. Activities to Support Staff Development in Collaborations

Regularly convene groups to provide a holistic view of the alliance. Given the portfolio of research that is being conducted with an alliance, there are often several different project leads from REL Midwest for each alliance. To prevent the project leads from becoming too siloed and losing sight of how a particular project connects and complements the others, the alliance lead convenes all of the project leads on a regular basis to discuss all of the projects. These meetings offer an opportunity for both the researchers and the alliance lead to provide updates on all of the projects and to discuss the challenges and successes experienced through the work of the SAGs. They also enable the researchers to hear from the alliance lead about the political context surrounding the work and the extent to which particular research questions are serving to inform certain alliance members and what might be done, in the interim, to further support those members who are less involved in the current portfolio of projects. Ultimately, these meetings support the alliance lead and the researchers in their efforts to look more holistically at the alliance and consider how to better nourish the partnership through the work they are doing. In addition to making a stronger connection between project leads and alliance leads, we convene monthly meetings between each alliance lead and the REL Midwest leadership team. During these meetings, we focus on all facets of our work with an alliance, including outreach activities, convenings, research and technical assistance projects, connections with similar alliances in other RELs, alliance-sponsored events, and engagement activities to support use. Although each of these activities is managed by a different leadership team member, these meetings allow us to see the interconnections of the work and to reflect on how well we are coherently meeting alliance needs.

Convene professional learning communities. In addition to establishing a structure that enables all REL Midwest staff to further develop their skills and knowledge about how best to serve a particular alliance, we believe it is important to offer staff development opportunities to our alliance leads and project leads through their own role-alike professional learning communities (PLCs).

The PLCs meet every other month. The meetings typically include facilitated discussions. For some meetings, we use prereadings about collaborative research or invited speakers and engage in activities to help us think about how to apply lessons learned to our context. At other times, we introduce or reexamine tools or structures to support our work. We allow our staff the opportunity to pilot new processes and provide input for improvement. We also support discussion about what supports are missing and how we might provide additional tools. Finally, some meetings come from staff-identified topics on challenges encountered and strategies they have developed to address these challenges. The goals of the PLCs are to provide our staff 
members with information on what collaboration is and the tools and resources available to support collaboration as well as create a network of colleagues who may serve as thought partners within and outside of the PLC structure.

Create feedback loops to learn about alliance building and processes. As we have moved the work on this project forward, we have developed methods and measures to track our progress on alliance building and to provide formative feedback for our work so that we might improve our practice of collaborative research from year to year. REL Midwest uses a variety of methods and tools to measure the degree to which our alliance leads and project leads are developing their collaborative skills. The information we gather through alliance surveys, interviews, and one-on-one calls with alliance members provides our staff members with multiple sources of information about the alliance members' perception of the partnership and the REL Midwest staff members' support. We also survey our researchers' perceptions of their collaborative skills to identify areas in which they believe they need the most support. This information helps us track our researchers' perceived change over time and learn which supports may have contributed to these perceived improvements. We examine this feedback regularly in leadership retreats and staff meetings. We also use the information to plan staff trainings and PLC topics. These data will inform alliance case studies and studies that examine changes in alliances over time to add to the emergent field of research on alliance building.

\section{Outputs That Serve as Proximal Indicators of Progress}

We developed the above processes based on our expectations for outputs that would be necessary to reach the ultimate outcomes of the program. We turned first to the nascent literature on collaborative research and expanded our review to include research on group processes. As noted in our processes section, we recognize the group dynamics at the alliance level and the research project level. That is, interactions occur between alliance members, facilitators, and researchers in the space of convenings, alliance-sponsored events, and communications through e-mails, newsletters, and one-on-one calls. In addition, interactions occur in project-specific meetings and communications with subsets of an alliance through the SAG. Therefore, some of our outputs fit at both the alliance and project levels, which is noted in our logic model by a mixed shading of the boxes in the full logic model (Figure 2) and the outputs section pulled out below in Figure 6 . 


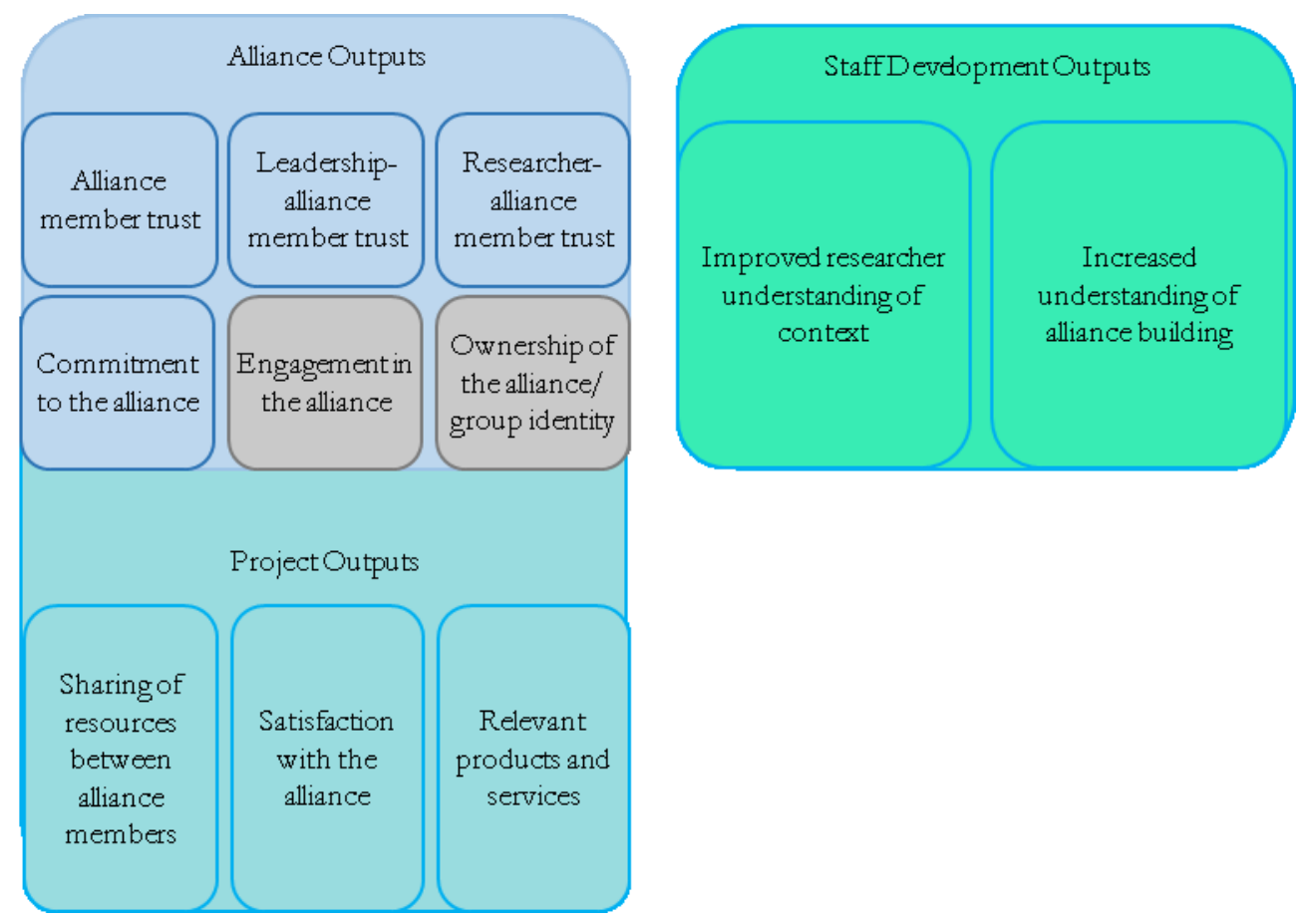

Figure 6. Collaborative Research Outputs

Trust. A consistent theme across the limited literature on research-practice partnerships is the importance of trust to the success of the collaboration (Clifford \& Millar, 2007; Committee on a Strategic Education Research Partnership, 2003; Roderick et al., 2009; Wentworth \& Khanna, 2011). Intuitively, it makes sense given that relationships are the key part of collaborative research models. Higher levels of trust may increase the likelihood of acquisition of research products from the alliance. The relationships also provide a platform for group sensemaking. Through these relationships, researchers may come to understand alliance member contexts to better design tools and supports that can accompany findings and help members use them in practice.

Case studies of collaborations most often discuss the need for trust between the researcher and practitioner (Cobb \& Jackson, 2012; D’Amico, 2010; Penuel, Fishman, Yamaguchi, \& Gallagher, 2007). In more complex collaborations, there is a recognition that trust must extend between multiple sets of researchers and practitioners. However, these cases usually discuss the need for a research organization to extend relationships to multiple levels of the practice organization. For example, Penuel, Fishman, Cheng, and Sabelli (2011) discuss their efforts to maintain relationships at the district, school, and classroom levels to successfully continue a research-practice partnership during periods of leadership change.

In our work, we differentiate between three types of trust-alliance lead-alliance member trust, researcher-alliance member trust, and member-member trust. Alliance leads maintain the first line of relationships with alliance members. They are the primary representative for the research organization and are responsible for laying the groundwork for positive relationships. Initially, alliance leads bridge the relationships between researchers and alliance members. However, as researchers work with alliance members on research projects, they develop their own relationships and have the opportunity to build higher levels of trust. Alliance leads continue to monitor relationships between the researchers and alliance members to identify any potential need for adjustments in communications or scope of work to preserve or build trust. 
Finally, the alliance lead serves as a broker to build trust between alliance members. In our alliances, members often come from different organizations. In most cases, members have some knowledge or experience with one another outside of the alliance. At times, those have been positive experiences that help set the stage for further positive interactions in this new context. Occasionally, alliance members come to an alliance with some level of distrust for other members based on past experiences. In those cases, alliance leads have invested additional time and discussion to create positive experiences between members in an effort to rebuild trust.

Commitment and satisfaction. Commitment to an organization is often cited as a precursor for further investment in an effort to reach the goals of the organization (Burke, 1997; Burke \& Reitzes, 1991; Burke \& Stets, 1999; Hogg \& Abrams, 1988). We look for demonstrations of commitment from alliance members during conversations either in convenings or in one-on-one check-ins. Members might discuss their enthusiasm for the alliance structure, the alignment between the alliance goals and their organizational goals, or the attribution of organizational or personal change to the alliance activities. Members who are highly committed to an alliance are also likely to express satisfaction with the alliance. However, members may be satisfied with an alliance while also maintaining low levels of commitment if an alliance is perceived to be useful in a limited way and the member is not looking for additional support. For example, we have experienced alliance members who turn to an alliance for a community of practice but are not extremely interested in the research or technical assistance projects that are the main work of the alliance. This low commitment/high satisfaction membership is not problematic if it describes a small number of members and there is a core of members with higher levels of commitment.

Engagement. Within our alliances, members have the opportunity to participate in a variety of activities that require different levels of investment. A base level of engagement comes from attending convenings and participating in discussions during convenings — a learner. Members may also partner with us to develop a convening agenda, host a convening, or present at a convening. Participation as an advisor for event planning or in a SAG for a project requires more time and effort. Finally, partnering with us on a research project as a champion by supplying data and/or study sites or by hosting a training requires a significant investment of personal and organizational resources to the alliance work. Alliance members may engage in a variety of ways at once and over time create a complex indicator of individual or organiza tional investment.

Engagement is necessary to produce relevant products and services that are more likely to be accessed and used. When members participate in our activities, the quality of the work improves. Our products become more tailored to the needs of our stakeholders. For example, through our SAGs, we learn how to better present findings to improve acquisition and interpretation in simple ways such as table formats and more complex ways such as the development of briefs that highlight different sets of findings for different audiences. Member engagement also raises the likelihood that members will use products and services because members feel more ownership of the results of the work. It is more difficult to dismiss challenging findings when individuals have been part of the effort. In addition, members who are invested are more likely to invest in difficult discussions about how to improve a project rather than distance themselves from the work and its results.

Resource sharing. Many of the mechanisms of engagement involve increased interactions between alliance members and staff from REL Midwest. We have also noted increased investment in the alliance demonstrated by alliance members sharing resources with one another. Building from alliance member trust, this sharing often appears as a community of practice. Members share information with each other about how similar challenges are addressed 
in their organizations. They may also provide templates or tools such as reporting formats or even programming code. In some cases, the community of practice has evolved to the joint pursuit of new projects that are beyond the scope of work of REL Midwest.

As resource sharing increases, the members gradually enter into group cycles of acquisition, interpretation, and sensemaking. In these cases, we have the opportunity to model the use of research evidence in this process. The alliance itself can serve as a model of interactions and structures to use internally for their individual organizations. Convening activities and agendas can be easily adapted for internal meetings. Resource banks, communication mechanisms, and discussion protocols can serve as models for members to use with their own staff.

Ownership. As members increase engagement levels through interaction with research staff and increased resource sharing with one another, they shape the group identity and incorporate the group membership into their own identity (Freese \& Burke, 1994; Thoits \& Virshup, 1997). Alliance branding and identity materials help support the emerging ownership by alliance members. Ownership of the alliance transfers to ownership of the alliance projects, products, and services. This sense of ownership feeds back into increasing investments to ensure the quality and relevance of alliance products and services. As discussed earlier, the individual investment increases the likelihood that these products and services will be accessed and used.

In some cases, member ownership has resulted in the emergence of group leaders among the alliance members. Members who consistently step forward to partner with our staff as champions or advisors on projects while also becoming a resource for fellow members may be ready to take on more of the leadership role for the alliance. In those cases, we have negotiated pared down responsibilities for our alliance leads and provided more administrative support for their leadership.

Relevant products and services. The alliance research products and services are the core work of the research organization and the primary goal of the alliance formation. In some cases, products and services are designed to provide skill-building opportunities to increase interpretation of data and research. In other cases, they intend to result in research findings that are easily accessed and used. As noted earlier, IES has made significant investments to increase the quality of education research and to educate stakeholders about what can be learned from various levels of evidence. If stakeholders do not believe the research is relevant to their context, they will not review it despite the high quality. Although our researchers are well trained to produce high-quality products, the alliance structure provides a new opportunity to make our work more relevant.

Improved researcher understanding of stakeholder context. To improve the relevance of our research and the quality of our engagement with stakeholders, we have focused on the development of our researchers. Our researchers needed to better understand the context of our alliance members to design studies and other products that support the use of findings. Researchers can gain an understanding of the context through discussions about specific projects, observation of convening discussions among alliance members, and a willingness to acknowledge the expertise alliance members bring to the collaboration. Our PLCs and SAGs are key structures to increase researcher understanding and skills in collaboration.

Increased understanding of alliance building. As a result of our feedback loops and reflections on our work, we expect to improve our work as alliance leads and researchers working with stakeholders. As we improve our skills as facilitators and partners, we expect the outputs from the alliance and project processes to improve as well. 


\section{Outcomes: Getting to Use}

The outcomes in our logic model follow the constructs discussed earlier in the review of literature on knowledge utilization. First, we aim to increase the acquisition of research by our alliance members and other education practitioners in similar roles. We work to make our products more accessible through SAG input on format and content and by becoming a more trusted source of quality information. Second, we focus on increasing the capacity to interpret research through the development of infographics, videos, and briefs that highlight findings in clear and concise language. In addition, we use convenings, workshops, debriefings, and events as platforms on which to jointly practice the interpretation of research and to model the group interpretation process. Finally, we support the conceptual and instrumental use of research not only by increasing the capacity to access and interpret research but also by working with our SAGs to produce research that is immediately relevant and useful and to surround published reports with tools, trainings, debriefings, and communication collateral that support our members as they attempt to move findings into practice. As noted earlier, increased knowledge utilization is the desired outcome for collaborative research. The inputs, processes, and outputs supply the components to map our progress toward that goal.

\section{Conclusion}

Emerging experiences suggest that collaborative research partnerships can benefit both research and practice. First, including practitioners on a research team can bridge the researchpractice divide, increasing the likelihood that research findings will be applied to practice (Coburn \& Stein, 2010; Roderick et al., 2009). As researchers and practitioners become part of the same social network, they also can become trusted sources of information for one another. In addition, it has been suggested that practitioner involvement in research can build capacity to incorporate systematic inquiry into decision-making processes within practitioner communities (Bryk et al., 2010a; Roderick et al., 2009). By modeling the research process, members of collaborative teams can incorporate what they learn into their own research acquisition and interpretation process. Finally, collaborative research also may inform the research process and education research itself by bringing together experts with diverse perspectives to engage in problem solving so that research and practice become part of an interactive cycle supporting improvement (Bryk \& Gomez, 2008; Bryk et al., 2010a). That is, researchers can gain a better understanding of how their work can be designed and conducted so it is directly relevant to practice.

Although we are increasing our understanding of the benefits of collaborative models, we lack clear models about how to carry out this work or how to track progress in building collaborations that might increase knowledge utilization. Our logic model on collaborative research maps our use of theories about knowledge utilization, group process, and trust formation to create structures and processes to promote collaboration to increase the use of research in educational practice. We view this as one step in a larger agenda about collaborative research. However, there are many steps ahead for us and others involved in this work. For example, in collaboration with a team at REL-NEI, we have developed and continue to refine measures of the constructs represented in this model. These measures are in early testing stages but show some promise. We continue to use these data along with qualitative and administrative data to assess our alliances and examine changes in alliance characteristics and use of research over time, but we do not have adequate numbers of alliances to model relationships represented in the logic model. Of course, we also recognize that our model is not representative of the 
work under way at the nine other RELs operating 71 other research alliances, nor is it representative of the many other research-practice partnerships under way. Our intention in presenting our model is not to present a definitive version of collaboration; rather, we intend it as an invitation for others involved in this work to document and display their own assumptions about their inputs, processes, outputs, and outcomes. In addition, we hope that it serves as a reference point for others starting this work.

\section{References}

Asen, R., Gurke, D., Conners, P., Solomon, R., \& Gumm, E. (2013). Research evidence and schoolboard deliberations: Lessons from three Wisconsin school districts. Educational Policy, 27, 33-63. http://dx.doi.org/10.1177/0895904811429291

Asen, R., Gurke, D., Solomon, R., Conners, P., \& Gumm, E. (2011). “The research says”: Definitions and uses of a key policy term in federal law and local school board deliberations. Argumentation and Advocacy, 47, 195-213.

Barnes, C., Goertz, M., \& Massell, D. (2014). How state education agencies acquire and use research knowledge for school improvement. In K. Finnigan \& A. Daly (Eds.), Using research evidence in education: From the schoolhouse door to Capitol Hill (pp. 99-116). Cham, Switzerland: Springer. http://dx.doi.org/10.1007/978-3-319-04690-7 8

Bryk, A. S., \& Gomez, L. (2008). Reinventing a research and development capacity. In F. M. Hess (Ed.), The future of educational entrepreneurship: Possibilities for school reform. (pp. 181-206). Cambridge, MA: Harvard Education Press.

Bryk, A. S., Gomez, L. M., \& Grunow, A. (2010a). Getting ideas into action: Building networked improvement communities in education. Stanford, CA: Carnegie Foundation for the Advancement of Teaching. Retrieved from http://cdn.carnegiefoundation.org/wpcontent/uploads/2014/09/bryk-gomez building-nics-education.pdf

Bryk, A. S., Sebring, P. B., Allensworth, E., Luppescu, S., \& Easton, J. Q. (2010b). Organizing schools for improvement: Lessons from Chicago. Chicago, IL: University of Chicago Press.

Burke, P. J. (1997). An identity model for network exchange. American Sociological Review, 62, 134-150. http://dx.doi.org/10.2307/2657456

Burke, P. J., \& Reitzes, D. C. (1991). An identity theory approach to commitment. Social Psychology Quarterly, 54, 239-251. http://dx.doi.org/10.2307/2786653Burke, P. J., \& Stets, J. E. (1999). Trust and commitment through self-verification. Social Psychology Quarterly, 62, 347-366. http://dx.doi.org/10.2307/2695833

Burkhardt, H., \& Schoenfeld, A. H. (2003). Improving educational research: Toward a more useful, more influential, and better-funded enterprise. Educational Researcher, 32(9), 3-14. http://dx.doi.org/10.3102/0013189X032009003

Clifford, M., \& Millar, S. B. (2007). K-20 partnership: A definition and proof of concept (WCER Working Paper No. 2007-9). Madison, WI: Wisconsin Center for Education Research. Retrieved from http://www.wcer.wisc.edu/publications/workingPapers/working paper no 2007 09.pdf

Cobb, P. A., \& Jackson, K. (2012). Analyzing educational policies: A learning design perspective. Journal of the Learning Sciences, 21(4), 487-521. http://dx.doi.org/10.1080/10508406.2011.630849Coburn, C. E. (2005). The role of nonsystem actors in the relationship between policy and practice: The case of reading instruction in California. Educational Evaluation and Policy Analysis, 27(1), 23-52. http://dx.doi.org/10.3102/01623737027001023 
Coburn, C. E., Honig, M. I., \& Stein, M. K. (2009). What's the evidence on districts' use of evidence? In J. Bransford, D. J. Stipek, N. J. Vye, L. Gomez, \& D. Lam (Eds.), The role of research in educational improvement (pp. 67-86). Cambridge, MA: Harvard Education Press.

Coburn, C. E., \& Stein, M. K. (Eds.). (2010). Research and practice in education: Building alliances, bridging the divide. Lanham, MD: Rowman \& Littlefield.

Committee on a Strategic Education Research Partnership. (2003). Strategic education research partnership. Washington, DC: National Academies Press. Retrieved from http://www.nap.edu/openbook.php?record id=10670

Corcoran, T., Fuhrman, S. H., \& Belcher, C. L. (2001). The district role in instructional improvement. Phi Delta Kappan, 83(1), 78-84. http://dx.doi.org/10.1177/003172170108300116

Daly, A. J., \& Finnigan, K. S. (2012). Exploring the space between: Social networks, trust, and urban school district leaders. Journal of School Leadership, 22(3), 493-530.

Daly, A. J., \& Finnigan, K. S. (Eds.). (2013). Systemwide reform: Examining districts under pressure [Special issue]. Journal of Educational Administration, 51(4). http://dx.doi.org/10.1108/jea.2013.07451daa.002

D’Amico, L. (2010). The Center for Learning Technologies in Urban Schools: Evolving relationships in design-based research. In C. E. Coburn \& M. K. Stein (Eds.), Research and practice in education: Building alliances, bridging the divide (pp. 37-53). Lanham, MD: Rowan \& Littlefield.

Finnigan, K. S., \& Daly, A. J. (2014). Using research evidence in education: From the schoolhouse door to Capitol Hill. New York, NY: Springer. http://dx.doi.org/10.1007/978-3-319-04690-7

Freese, L., \& Burke, P. J. (1994). Persons, identities, and social interaction. In B. Markovsky, K. Heimer, \& J. O’Brien (Eds.), Advances in group processes (pp. 1-24). Greenwich, CT: JAI Press.

Fusarelli, L. D. (2008). Flying (partially) blind: School leaders' use of research in decision making. Phi Delta Kappan, 89(5), 365-368. http://dx.doi.org/10.1177/003172170808900512

Glennan, T. K., Jr., Bodilly, S. J., Galegher, J. R., \& Kerr, K. A. (2004). Expanding the reach of education reforms: Perspectives from leaders in the scale-up of educational interventions. Santa Monica, CA: RAND. Retrieved from http://www.rand.org/content/dam/rand/pubs/monographs/2004/RAND MG248.pdf

Hess, F. M. (2008). When education research matters (Education Outlook). Washington, DC: American Enterprise Institute for Public Policy Research. Retrieved from http://www.aei.org/wpcontent/uploads/2011/10/20080201 0122641EduOFeb g.pdf

Hiebert, J., Gallimore, R., \& Stigler, J. W. (2002). A knowledge base for the teaching profession: What would it look like and how can we get one? Educational Researcher, 31(5), 3-15. http://dx.doi.org/10.3102/0013189X031005003

Hogg, M. A., \& Abrams, D. (1988). Social identifications: A social psychology of intergroup relations and group processes. London: Routledge.

Honig, M. I. (2006). Street-level bureaucracy revisited: District central office administrators as boundary spanners in complex policy implementation. Educational Evaluation and Policy Analysis, 28, 357-383. http://dx.doi.org/10.3102/01623737028004357

Honig, M. I., \& Coburn, C. (2008). Evidence-based decision making in school district central offices: Toward a policy and research agenda. Educational Policy, 22, 578-608. http://dx.doi.org/10.1177/0895904807307067

Hubbard, L. (2010). Research to practice: The case of Boston Public Schools, education matters and Boston plan for excellence. In C. Coburn \& M. K. Stein (Eds.), Research and practice in education: Building alliances, bridging the divide. Lanham, MD: Rowman \& Littlefield. 
Kaner, S. (2007). Facilitator's guide to participatory decision-making (2nd ed.). San Francisco, CA: JosseyBass.

Kennedy, M. M. (1982). Working knowledge. In M. M. Kennedy (Ed.), Working knowledge and other essays (pp. 1-28). Cambridge, MA: Huron Institute.

Kochanek, J. R., \& Clifford, M. (2014). Trust in districts: The role of relationships in policymaking for school improvement. In D. Van Maele, P. B. Forsyth, \& M. Van Houtte (Eds.), Trust and school life: The role of trust for learning, teaching, leading, and bridging (pp. 313-334). New York, NY: Springer. http://dx.doi.org/10.1007/978-94-017-8014-8 14Lagemann, E. C. (2002). Usable knowledge in education: A memorandum for the Spencer Foundation board of directors. Chicago, IL: Spencer Foundation.

McDonnell, L. M., \& Weatherford, M. S. (2014). Research evidence and the Common Core State Standards. In K. Finnigan \& A. Daly (Eds.), Using research evidence in education: From the schoolhouse door to Capitol Hill (pp. 117-132). Cham, Switzerland: Springer. http://dx.doi.org/10.1007/978-3-319-04690-7 9

Penuel, W. R., Fishman, B. J., Cheng, B., \& Sabelli, N. (2011). Organizing research and development at the intersection of learning, implementation, and design. Educational Researcher, 40(7), 331-337. http://dx.doi.org/10.3102/0013189X11421826

Penuel, W. R., Fishman, B. J., Yamaguchi, R., \& Gallagher, L. P. (2007). What makes professional development effective? Strategies that foster curriculum implementation. American Educational Research Journal, 44(4), 921-958. http://dx.doi.org/10.3102/0002831207308221Research Alliance for New York City Schools. (2011). Learning from New York City's portfolio strategy: How policy and practice can inform research. New York, NY: Author.

Roderick, M., Easton, J., \& Sebring, P. (2009). The Consortium on Chicago School Research: A new model for the role of research in supporting urban school reform. Chicago, IL: Consortium on Chicago School Research. Retrieved from https://ccsr.uchicago.edu/sites/default/files/publications/CCSR $\% 20$ Model $\% 20$ Reportfinal.pdf

Thoits, P. A., \& Virshup, L. K. (1997). Me's and we's: Forms and functions of social identities. In R. D. Ashmore \& L. J. Jussim (Eds.), Self and identity: Fundamental issues (pp. 106-133). New York, NY: Oxford University Press.

Tseng, V. (2012). The uses of research in policy and practice (Social Policy Report 26[2]). Ann Arbor, MI: Society for Research in Child Development. Retrieved from http://files.eric.ed.gov/fulltext/ED536954.pdf

Weiss, C. H. (1980). Knowledge creep and decision accretion. Knowledge: Creation, Diffusion, Utilization, 1(3), 381-404. http://dx.doi.org/10.3102/0002831207308221

Weiss, C. H., Murphy-Graham, E., \& Birkeland, S. (2005). An alternate route to policy influence: How evaluations affect D.A.R.E. American Journal of Evaluation, 26(12), 12-30. http://dx.doi.org/10.1177/1098214004273337

Wentworth, L., \& Khanna, R. (2011, April). Partnering around research to improve policy and practice: A case study of the Stanford University and San Francisco Unified School District Partnership. Paper presented at American Educational Research Association annual meeting, New Orleans, LA.

\section{About the Authors}




\section{Julie Reed Kochanek}

American Institutes for Research

jkochanek@air.org

Julie R. Kochanek, Ph.D., is a managing director at American Institutes for Research (AIR). Dr. Kochanek directs the Regional Educational Laboratory (REL) Midwest, a \$38-million research center funded by the Institute of Education Sciences (IES). In addition to her work on REL Midwest, she works to develop and grow additional research-practice partnerships between AIR and state education agencies and districts across the country.

\section{Carrie Scholz}

American Institutes for Research

cscholz@air.org

Carrie Scholz, Ph.D., is a senior researcher at AIR and oversees the REL Midwest research alliances. In addition to her work on REL Midwest, she works to develop and grow additional researchpractice partnerships between AIR and state education agencies and districts across the country.

\section{Alicia N. Garcia}

American Institutes for Research, agarcia@air.org

Alicia N. Garcia, J.D., is a senior policy analyst at AIR and serves as the deputy director for REL Midwest. In addition to her work on REL Midwest, she works to develop and grow additional research-practice partnerships between AIR and state education agencies and districts across the country.

\section{About the Co-Guest Editors}

\section{Dr. Amanda Cooper}

Queen's University

amanda.cooper@queensu.ca

Dr. Amanda Cooper, a former secondary school teacher, is an Assistant Professor in

Educational Policy and Leadership at Queen's University in Canada. She is the Principal Investigator of RIPPLE - Research Informing Policy, Practice and Leadership in Education (www.ripplenetwork.ca) - a program of research, training and $\mathrm{KMb}$ aimed at learning more about how knowledge brokering $(\mathrm{KB})$ can increase research use and its impact in public service sectors by facilitating collaboration between multi-stakeholder networks.

\section{Samantha Shewchuk}

Queen's University

s.shewchuk@queensu.ca

Samantha Shewchuk is an elementary school teacher and a doctoral student in the Faculty of Education at Queen's University. Her research explores knowledge mobilization at the intersection of the education and child welfare sectors; more specifically, how outcomes for abused children can be improved by increasing research use in these sectors. She is the program manager of Dr. Amanda Cooper's RIPPLE program, Research Informing Policy Practice and Leadership in Education (www.ripplenetwork.ca) 


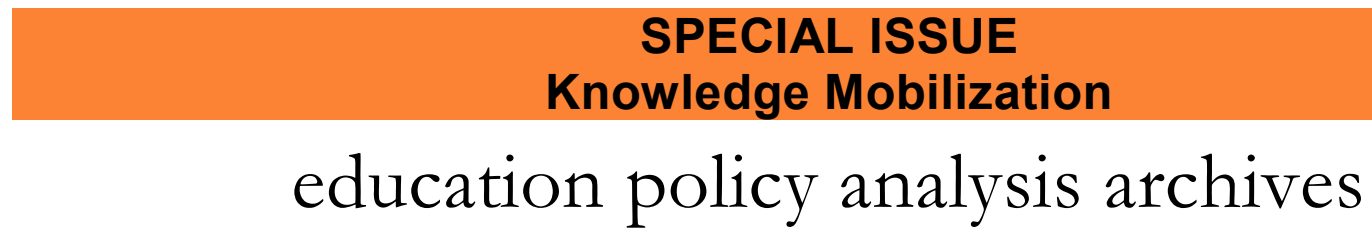

Volume 23 Number 121

December 7, 2015

ISSN 1068-2341

()

SOMERIIGHISRESERVED Readers are free to copy, display, and distribute this article, as long as the work is attributed to the author(s) and Education Policy Analysis Archives, it is distributed for noncommercial purposes only, and no alteration or transformation is made in the work. More details of this Creative Commons license are available at http://creativecommons.org/licenses/by-nc-sa/3.0/. All other uses must be approved by the author(s) or EPAA. EPAA is published by the Mary Lou Fulton Institute and Graduate School of Education at Arizona State University Articles are indexed in CIRC (Clasificación Integrada de Revistas Científicas, Spain), DIALNET (Spain), Directory of Open Access Journals, EBSCO Education Research Complete, ERIC, Education Full Text (H.W. Wilson), QUALIS A2 (Brazil), SCImago Journal Rank; SCOPUS, SOCOLAR (China).

Please contribute commentaries at http://epaa.info/wordpress/ and send errata notes to Gustavo E. Fischman fischman@asu.edu

Join EPAA's Facebook community at https://www.facebook.com/EPAAAAPE and Twitter feed@epaa_aape. 


\section{education policy analysis archives editorial board}

Editor Gustavo E. Fischman (Arizona State University)

Associate Editors: Audrey Amrein-Beardsley (Arizona State University), Rick Mintrop, (University of California, Berkeley) Jeanne M. Powers (Arizona State University)

Jessica Allen University of Colorado, Boulder

Gary Anderson New York University

Michael W. Apple University of Wisconsin, Madison

Angela Arzubiaga Arizona State University

David C. Berliner Arizona State University

Robert Bickel Marshall University

Henry Braun Boston College

Eric Camburn University of Wisconsin, Madison

Wendy C. Chi* University of Colorado, Boulder

Casey Cobb University of Connecticut

Arnold Danzig Arizona State University

Antonia Darder University of Illinois, UrbanaChampaign

Linda Darling-Hammond Stanford University

Chad d'Entremont Strategies for Children

John Diamond Harvard University

Tara Donahue Learning Point Associates

Sherman Dorn University of South Florida

Christopher Joseph Frey Bowling Green State University

Melissa Lynn Freeman* Adams State College

Amy Garrett Dikkers University of Minnesota

Gene V Glass Arizona State University

Ronald Glass University of California, Santa Cruz

Harvey Goldstein Bristol University

Jacob P. K. Gross Indiana University

Eric M. Haas WestEd

Kimberly Joy Howard* University of Southern California

Aimee Howley Ohio University

Craig Howley Ohio University

Steve Klees University of Maryland

Jaekyung Lee SUNY Buffalo
Christopher Lubienski University of Illinois, UrbanaChampaign

Sarah Lubienski University of Illinois, UrbanaChampaign

Samuel R. Lucas University of California, Berkeley

Maria Martinez-Coslo University of Texas, Arlington

William Mathis University of Colorado, Boulder

Tristan McCowan Institute of Education, London

Heinrich Mintrop University of California, Berkeley

Michele S. Moses University of Colorado, Boulder

Julianne Moss University of Melbourne

Sharon Nichols University of Texas, San Antonio

Noga O'Connor University of Iowa

João Paraskveva University of Massachusetts, Dartmouth

Laurence Parker University of Illinois, UrbanaChampaign

Susan L. Robertson Bristol University

John Rogers University of California, Los Angeles

A. G. Rud Purdue University

Felicia C. Sanders The Pennsylvania State University Janelle Scott University of California, Berkeley

Kimberly Scott Arizona State University

Dorothy Shipps Baruch College/CUNY

Maria Teresa Tatto Michigan State University

Larisa Warhol University of Connecticut

Cally Waite Social Science Research Council

John Weathers University of Colorado, Colorado Springs

Kevin Welner University of Colorado, Boulder

Ed Wiley University of Colorado, Boulder

Terrence G. Wiley Arizona State University

John Willinsky Stanford University

Kyo Yamashiro University of California, Los Angeles

* Members of the New Scholars Board 


\section{archivos analíticos de políticas educativas consejo editorial}

Editor: Gustavo E. Fischman (Arizona State University)

Editores. Asociados Alejandro Canales (UNAM) y Jesús Romero Morante (Universidad de Cantabria)

Armando Alcántara Santuario Instituto de Investigaciones sobre la Universidad y la Educación, UNAM México

Claudio Almonacid Universidad Metropolitana de Ciencias de la Educación, Chile

Pilar Arnaiz Sánchez Universidad de Murcia, España

Xavier Besalú Costa Universitat de Girona, España Jose Joaquin Brunner Universidad Diego Portales, Chile

Damián Canales Sánchez Instituto Nacional para la Evaluación de la Educación, México

María Caridad García Universidad Católica del Norte, Chile

Raimundo Cuesta Fernández IES Fray Luis de León, España

Marco Antonio Delgado Fuentes Universidad Iberoamericana, México

Inés Dussel FLACSO, Argentina

Rafael Feito Alonso Universidad Complutense de Madrid, España

Pedro Flores Crespo Universidad Iberoamericana, México

Verónica García Martínez Universidad Juárez Autónoma de Tabasco, México

Francisco F. García Pérez Universidad de Sevilla, España

Edna Luna Serrano Universidad Autónoma de Baja California, México

Alma Maldonado Departamento de Investigaciones Educativas, Centro de Investigación y de Estudios Avanzados, México

Alejandro Márquez Jiménez Instituto de Investigaciones sobre la Universidad y la Educación, UNAM México

José Felipe Martínez Fernández University of California Los Angeles, USA
Fanni Muñoz Pontificia Universidad Católica de Perú

Imanol Ordorika Instituto de Investigaciones Economicas - UNAM, México

Maria Cristina Parra Sandoval Universidad de Zulia, Venezuela

Miguel A. Pereyra Universidad de Granada, España

Monica Pini Universidad Nacional de San Martín, Argentina

Paula Razquin UNESCO, Francia

Ignacio Rivas Flores Universidad de Málaga, España

Daniel Schugurensky Universidad de Toronto-Ontario Institute of Studies in Education, Canadá

Orlando Pulido Chaves Universidad Pedagógica Nacional, Colombia

José Gregorio Rodríguez Universidad Nacional de Colombia

Miriam Rodríguez Vargas Universidad Autónoma de Tamaulipas, México

Mario Rueda Beltrán Instituto de Investigaciones sobre la Universidad y la Educación, UNAM México

José Luis San Fabián Maroto Universidad de Oviedo, España

Yengny Marisol Silva Laya Universidad Iberoamericana, México

Aida Terrón Bañuelos Universidad de Oviedo, España

Jurjo Torres Santomé Universidad de la Coruña, España

Antoni Verger Planells University of Amsterdam, Holanda

Mario Yapu Universidad Para la Investigación Estratégica, Bolivia 


\section{arquivos analíticos de políticas educativas conselho editorial}

Editor: Gustavo E. Fischman (Arizona State University)

Editores Associados: Rosa Maria Bueno Fisher e Luis A. Gandin

(Universidade Federal do Rio Grande do Sul)

Dalila Andrade de Oliveira Universidade Federal de Minas Gerais, Brasil

Paulo Carrano Universidade Federal Fluminense, Brasil

Alicia Maria Catalano de Bonamino Pontificia Universidade Católica-Rio, Brasil

Fabiana de Amorim Marcello Universidade Luterana do Brasil, Canoas, Brasil

Alexandre Fernandez Vaz Universidade Federal de Santa Catarina, Brasil

Gaudêncio Frigotto Universidade do Estado do Rio de Janeiro, Brasil

Alfredo M Gomes Universidade Federal de Pernambuco, Brasil

Petronilha Beatriz Gonçalves e Silva Universidade Federal de São Carlos, Brasil

Nadja Herman Pontificia Universidade Católica -Rio Grande do Sul, Brasil

José Machado Pais Instituto de Ciências Sociais da Universidade de Lisboa, Portugal

Wenceslao Machado de Oliveira Jr. Universidade Estadual de Campinas, Brasil
Jefferson Mainardes Universidade Estadual de Ponta Grossa, Brasil

Luciano Mendes de Faria Filho Universidade Federal de Minas Gerais, Brasil

Lia Raquel Moreira Oliveira Universidade do Minho, Portugal

Belmira Oliveira Bueno Universidade de São Paulo, Brasil

António Teodoro Universidade Lusófona, Portugal

Pia L. Wong California State University Sacramento, U.S.A

Sandra Regina Sales Universidade Federal Rural do Rio de Janeiro, Brasil

Elba Siqueira Sá Barreto Fundação Carlos Chagas, Brasil

Manuela Terrasêca Universidade do Porto, Portugal

Robert Verhine Universidade Federal da Bahia, Brasil

Antônio A. S. Zuin Universidade Federal de São Carlos, Brasil 